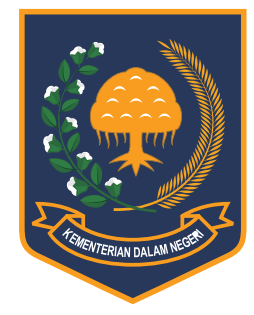

Jurnal Bina Praja 10 (1) (2018): 1-12

Jurnal Bina Praja

e-ISSN: 2503-3360 | p-ISSN: 2085-4323

Accreditation Number

735/AU2/P2MI-LIPI/04/2016

http://jurnal.kemendagri.go.id/index.php/jbp/index

\title{
Stochastic Dominance Analysis for The Poverty IN TABALONG REgENCY 2013 AND 2017
}

\author{
Ahmadi Murjani* \\ Statistics of Tabalong Regency \\ Jalan Jaksa Agung Soeprapto No. 82 Tanjung, \\ Tabalong Regency, South Kalimantan, Indonesia
}

Received: 20 January 2018; Accepted: 18 April 2018; Published online: 12 May 2018

DOI: $10.21787 / j b p .10 .2018 .01-12$

\begin{abstract}
Although its issue could be addressed from of various perspectives over the years, poverty is the object of the government's policy programs to be alleviated since the Indonesian independence. With the advancement of technology and science in the recent decades, the availability and the completeness of poverty data in Indonesia getting better. In fact, the policy-makers can assess the effectivity of their public-oriented programs easier by effectively utilizing the complete and up-to-date poverty data. However, in various approaches to poverty measurement, the Indonesian poverty data should be accompanied by another approach. This paper aims to evaluate the change of welfare of particular region over a period of several years by using the stochastic dominance method. This method also incorporates the price level impact into its poverty assessment through the extrapolated CPIs. To conduct the measurement, the National Socioeconomic Survey of Tabalong regency data, as well as the Tanjung city's inflation in the period from 2013 to 2017, are employed. The results indicate that the welfare in 2017 is better than in 2013 since the distribution in 2017 stochastically dominates the distribution in 2013 at the first and second order at any possible level of poverty lines. Therefore, this result could also be the additional input for the poverty alleviation's evaluation in order to provide a solid conclusion about the welfare changes.
\end{abstract}

Keywords: Tabalong, Stochastic Dominance, Poverty, Welfare, Cumulative Distribution Function

\section{INTRODUCTION}

Poverty is a complex problem and can be addressed in many ways because it is highly mixed with every aspect of living; for instance, social, economic, culture, etc. In fact, the various efforts have been being done to overcome the poverty problem since the independence of Indonesia. One of the important aspects that should be underlined is the availability of the poverty data, the accurate data to be emphasized. It is mandatory since the policy-making process needs the valid and reliable data. A good poverty data can be utilized to evaluate the effectiveness of the government's policy on the poverty, comparable time to time and interregional, and also able to put the targeting poor people as the subjects to receive the benefit of poverty alleviation programs (Statistics Indonesia (BPS), 2016).
The concept of poverty could be addressed in many ways. On one standing, it can be seen as a relative subject while others see it as an absolute substance (Statistics Indonesia (BPS), 2016). Suyanto (2001) translated poverty not only considers on materials but also abstract subjects such as fragility, powerless, etc. While the World Bank (in Statistics Indonesia (BPS), 2016) mentioned poverty as the deprivation of well-being, MacPherson \& Silburn (1998) simplify it with the notion of the basic lack of surviving. There is no doubt that the poverty concept differs as well as its measurement.

In Indonesia, poverty is examined by Statistics Indonesia (hereafter, BPS). In line with Lanjouw's statement (1998), Indonesia has been joining majority countries to use expenditure approach in calculating poverty. BPS (2009) explained that

\footnotetext{
* Corresponding Author

Phone : +62 85248888473

Email : ahmadimurjani@gmail.com
} 
Indonesia has been providing the poverty data covering the period of 1970 to 1996 (using the old method) and the period of 1996 to 2017 (using the new method). In the recent years, BPS also provided the poverty data twice a year since 2011.

The poverty data series can be observed on the World Bank website (through the World Development Indicators (WDI)) and BPS' website (in the Poverty and Inequality section). Furthermore, WDI also provides the poverty rate using the dollara-day approach for Indonesia as a comparison.

BPS provides not only the percentage of poor people data on its website but also other poverty indices such as poverty depth index and poverty severity index. Furthermore, those indices are also available in time series comprising provinces in Indonesia. Thus, these series seems appropriate to draw the poverty alleviation progress in Indonesia.

As an official statistic of the poverty measurement in Indonesia, the poverty data synthesized by BPS stands among some considerations from researchers in Indonesia. Marbun \& Suryahadi (2009), Susilowati (2010), and recently Khomsan et al. (2015), delivered some findings in their research that highly concerning not only the poverty calculation method but also highlighting the low rate of poverty measurement produced by BPS. Thus, this paper aims to measure the wealth change over specific period using the method that considers the flexibility of a range of poverty lines as well as the poverty rates produced.

In regards for some previous issues highlighting the uncertainty in the poverty calculation due to the chosen poverty line, Atkinson (1987) proposed the new method to measure poverty based on the change of welfare reflected from the stochastic ordering of the per capita expenditures from the cumulative distribution function. The strength of this method is that the welfare change could be examined in a range of some poverty thresholds; therefore, the chosen poverty lines could accommodate various suggested poverty lines. Hence, this method describes the sensitivity of the chosen poverty line. However, as a weakness of this method, the exact poverty rate could not be advised because the analysis runs in a range of thresholds. So, this method could only describe the welfare change regardless the quantity of the changes.

This paper elaborates the long-ago research conducted by Ravallion \& Huppi (1991) as the background. They investigated the poverty changes in the period of 1984 and 1987 using the National Socioeconomic Surveys (Susenas) in Indonesia. They focused on constructing the new poverty rate using the purchasing power parity approach, decomposing those measurements, and comparing them.

Formulated by Foster, Greer, and Thorbecke in 1984, known as FGT indices, Ravallion and
Huppi deflated the base year's poverty line with modified consumer price index (CPI) and differed the CPI into the urban and the rural areas, and then multiplied by the purchasing power parity. There were some reasons why they examined the poverty alleviation progress in 1984 and 1987 using a different poverty approach compared with Indonesia's poverty measurements. Two of reasons were about the changing the relative price of goods and services, and rupiah's devaluation over periods. These backgrounds illustrated the poverty calculation using real data, rather than the nominal figures. Eventually, as it is possible, the construction of similar research by utilizing the predefined domestic poverty lines in the different time frame and economic situation is essential.

Indeed, the research conducted by Ravallion and Huppi in 1991 is likely to be presented in the recent periods in order to provide further comprehensive analysis of poverty comparison over the periods in Indonesia. However, there are limited published papers focusing on this comparison especially in Indonesia. Ravallion and Huppi utilized the previously-introduced method by Atkinson (1987) so-called the Stochastic Dominance analysis on the poverty in their research.

Ultimately, this paper examines the poverty or welfare comparison to justify whether the poverty indeed declines (increasingwelfare) over the periods by using Tabalong regency of South Kalimantan province, Indonesia data in the period 2013 to 2017. Moreover, this paper uses the Stochastic Dominance analysis to see the robustness of the poverty figure and also the sensitivity of the domestic poverty lines to the poverty rate produced.

After revealing the results, there will be some concluding remarks regarding the poverty in Tabalong regency in the period 2013 to 2017 . There are three sections remaining for this paper: method, result, and conclusion.

\section{A. Tabalong's Regency Poverty Figures}

Among 13 cities and regencies in South Kalimantan, Tabalong was the second highest regency for the poverty rate by $6.35 \%$ in 2016 , it was one position under Hulu Sungai Utara regency that possessed the poverty rate by $6.76 \%$. In the absolute number, Tabalong regency contained the sixth-highest poor people (BPS Provinsi Kalimantan Selatan, 2017). Tabalong's regency poverty data can be obtained from BPS-Statistics of South Kalimantan Province and BPS-Statistics of Tabalong Regency, available from 1996 to 2017. Furthermore, the poverty lines are available in the period 2002-2017.

Figure 1 depicts the trends of poverty rates and poverty lines in Tabalong regency in 1996 to 2017 and 2002 to 2017 respectively. It is clearly seen that in between 1996 and 1999 there was a 

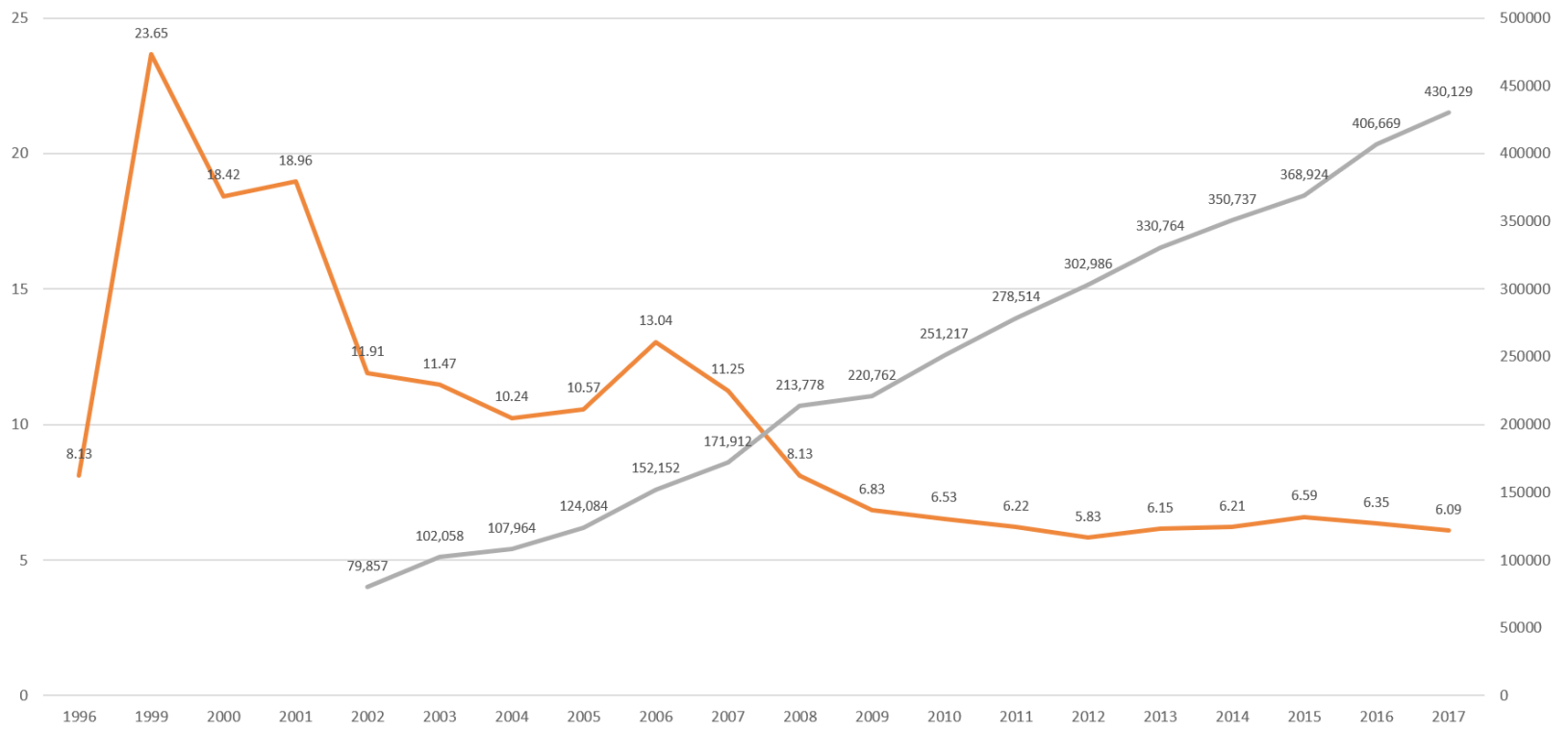

- Poverty Rate Poverty Line

Figure 1. The Trends of Poverty Rates (\%) and Poverty Lines (Rupiah) in Tabalong Regency, 1996-2017, and 2002-2017

Source: BPS

significant increase in the poverty rate due to a highly-impacting shock which was an economic crisis. After that, the poverty rate declined gradually. Starting in 2008, Tabalong's poverty rate touched single digit number (8.13\%) until 2017 (6.09\%). There was no significant increase in term of poverty rate fluctuation since 2008 . The poverty rate was below $10 \%$ constantly. In term of poverty line's development, there is a clear trend shown in Figure 1, from 2002 to 2017 poverty lines inclined in the same manner, increased gradually with relatively same slopes.

Focusing on the slopes, the declining of poverty rates in Tabalong regency can be divided into two sections. The first section occurred in the period 1999 to 2007, the section that depicted the years after the economic shock in 1997-1998. The slope of the trend was steep, showing a high progress of poverty rate reduction. In these years, poverty rates were in double-digit numbers. In the second section, the period 2007 to 2017 , the poverty rates were only in a single digit (under $10 \%$ ). Based on the slope of the poverty rates trend in these years, the poverty reduction seems slow, shown by the flatter slope of the trend line.

\section{B. Theoretical Background}

BPS initially calculated Indonesia's poverty rate data in 1984. At once, the calculation covered years 1976 to 1981 by utilizing Susenas consumption module data. After that, once in every three years, BPS provided the poverty rate data divided by the urban and the rural areas. Moreover, since 2003, BPS has been presenting the poverty rate data annually (BPS, 2016a).

BPS (2016a) has been adopting the basic-need approach since initially calculated poverty. The measurement of the poverty rate comprised of 52 of food commodities in the urban and the rural areas while for the non-food commodities covered 51 items in the urban areas and 47 items in the rural areas. Using this approach, the poverty is addressed as a lack of the economic ability to satisfy those basic needs for food and non-food measured from the expenditure; eventually, these thresholds become a poverty line. Poor people are those who possess the per capita per month expenditure below the poverty line.

\section{1) FGT Indices}

After the poverty line is set, further calculation of the household data can be done to develop a poverty figure. BPS has been utilizing the wellknown poverty measurement so-called FosterGreer-Thorbecke (FGT) Indices (1984), given by

$$
\mathrm{P}_{\alpha}=\frac{1}{n} \sum_{y_{i}<z}^{n}\left(\frac{z-y_{i}}{z}\right)^{\alpha}
$$

where $\mathrm{P}_{\alpha}$ is FGT index $\left(\alpha=0\right.$ translated as $\mathrm{P}_{0}$ or poverty rate/incident, $\alpha=1$ translated as $P_{1}$ or poverty gap ratio, $\alpha=2$ translated as $P_{2}$ or poverty severity index), $n$ is the number of samples, $y_{i}$ is per 
capita income household $i$ (household weight for individual is need to draw per capita figure), and $z$ is the poverty line. Instead of using an income for $y$, BPS employed the expenditure data to substitute income.

\section{2) Stochastic Dominance Analysis in Poverty}

Stochastic dominance is defined as a set of correlations that connect between two distributions. The application of the stochastic dominance varies over many disciplines, one of which is in poverty analysis. The most common application in the poverty analysis is examining income distribution and income inequality (Davidson, 2006). Initially introduced on the poverty analysis by Atkinson (1987), this method is then utilized by many researches.

The bottom line for the connection between poverty and the stochastic dominance is on the poverty indices (FGT). Davidson \& Duclos (2000) illustrated in the following explanations and equations.

Having two distributions of expenditures (taken from, i.e., Susenas data), then arranged into two cumulative distribution functions (CDFs) named $F_{A}$ and $F_{B}$ with the property of a non-negative number. Here, expenditures are the manifestation of welfare. Set $D \frac{1}{A}(x)=F_{A}(x)$ and

$$
D_{A}^{s}(\chi)=\int_{0}^{\chi} D_{A}^{s-1}(y) d y
$$

for any integer $s \geq 2$ and consider $D_{B}^{s}(\chi)$ is comparable. For any order of $s, D^{s}(x)$ can be expressed as

$$
D^{s}(\chi)=\frac{1}{(s-1) !} \int_{0}^{\chi}(\chi-y)^{s-1} d F(y)
$$

Distribution $B$ can be addressed dominate the distribution $A$ stochastically at the order $s$ when $D_{A}^{s}(x) \geq D_{B}^{s}(x)$ for all $x \in R$. Suppose the poverty line is $z>0$, then $B$ is stochastically dominates $A$ at order s up to the poverty line $z$ if $D_{A}^{s}(x) \geq D_{B}^{s}(x)$ for all $x \leq z$. Connected with the previous notion, it is concluded that $F_{A}(x) \geq F_{B}(x)$ for all $x \leq z$. In other words, the poverty rate is always bigger in $A$ than in $B$, as long as the poverty line does not exceed $z$. This notion is also known as the First-order stochastic dominance.

Second-order stochastic dominance of $A$ by $B$ up to poverty line $z$ expressed as $D_{A}^{2}(x) \geq D_{B}^{2}(x)$ implied in

$$
\int_{0}^{x}(x-y) d F_{A}(y) \geq \int_{0}^{x}(x-y) d F_{B}(y)
$$

for all $x \leq z$. With poverty line $z$, the poverty gap with expenditure $y$ is expressed as

$$
g(z, y)=(z-y)_{+}=\max (z-y, 0)=z-y^{*}
$$

where equation (5) draws a poverty gap area underneath the $D_{B}^{2}(x)$ when poverty line equal to $Z$; therefore, the total area become $D_{B}^{2}(z)$. When $B$ stochastically dominates $A$ at poverty line $z$, in the second-order dominance, $D_{A}^{2}(z) \geq D_{B}^{2}(z)$. It can be concluded that the poverty gap in $A$ always bigger than in $A$ when $B$ stochastically dominates $A$ at the poverty line $z$. Based on these two-times ordering, it is clear that when $B$ stochastically dominates $A$, the poverty rate as well as the poverty gap in $B$ always smaller than $A$, it can be said that the welfare in $B$ is better than in $A$. Davidson and Duclos also notified that for the next order, the condition also holds (the poverty severity condition is formed at the third order).

\section{3) The Sensitivity of the Poverty Line to the Poverty}

Previously, the notion $B$ stochastically dominates $A$ would be addressed as the welfare in $B$ is better than in $A$, depicted by the CDFB and the CDFA. Let's take the example from the research conducted by Ravallion \& Huppi (1991) in Indonesia as follow

Figure 2 shows that, in general, the welfare in Indonesia in 1987 was better than in 1984 because stochastically the monthly consumption per person in 1987 dominated the other in 1984. It is also can be seen, when the 1984 and 1987 CDF curves spread in some distances, the chosen poverty line would yield the lower poverty rate in 1987 . When those CDF curves are united, or even crossing each other (as can be seen in Figure 3), the poverty

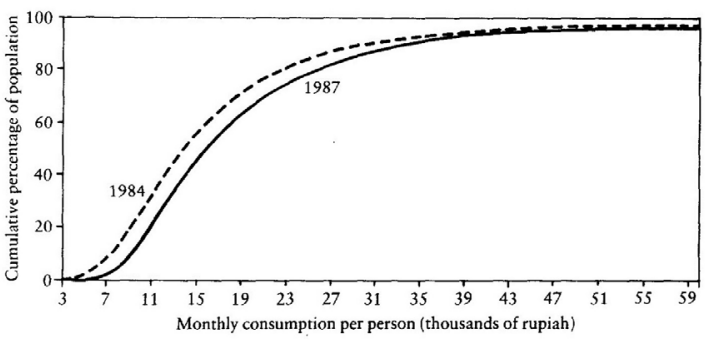

Figure 2. Distribution of Monthly Per Capita Consumption in Indonesia, 1984 and 1987

Source: Ravallion \& Huppi (1991) 


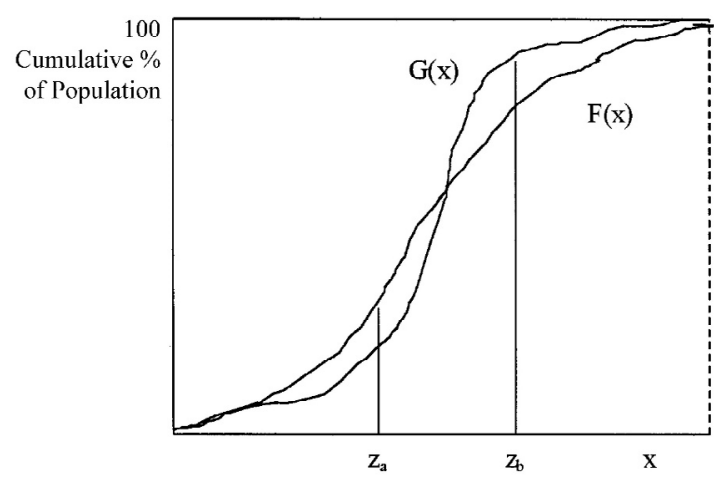

Figure 3. The Cross of Poverty Incidence Curves

Source: Madden \& Smith (2000)

line set now is so-called sensitive to the poverty rate produced, because the poverty rate for $G(x)$ either can be higher or lower than $F(x)$. The close position between two CDF lines can describe the sensitiveness of the chosen position poverty line. In the method section, there will be a particular step to determine the dominance regarding this sensitivity.

Based on Figure 3, at the poverty line $z_{a^{\prime}}$ it is can be said that $G(x)$ stochastically dominates $F(x)$; and at poverty line $z_{b}, F(x)$ stochastically dominates $G(x)$. So, both situations are called restricted dominance because it depends on the particular poverty line. Hence, the chosen poverty line is sensitive to the poverty.

To determine which distribution dominates aggregately, the areas beneath the CDFs need to be calculated as mentioned in equation 4 . When the dominance does not hold at the first order, the situation in Figure 3 is called second-order domination.

\section{Stochastic Dominance in Poverty: Empirical Applications}

\section{1) Application in the Poverty Analysis}

Atkinson (1987) introduced the application of the stochastic dominance in poverty by drawing the cumulative percentage below different poverty levels against the unit of the percentage of the official poverty line in the United States for 1974, 1979, and 1982. He decomposed the possible poverty measurements using such illustration.

Chosen poverty line can be critical in determining the exact value of a poverty (welfare). Thus, with the inappropriate poverty line, the conclusion can be ambiguous. Foster \& Shorrocks (1988) underlined such problem in their research. To overcome the problem, they suggested a method that examines the partial ordering of various poverty indices. This method yielded poverty orderings and welfare dominance. The calculation might be different with the stochastic dominance; however, the main idea relatively similar, forming a dominance figure.

In Indonesia, Ravallion \& Huppi (1991) investigated the poverty reduction progress by employing the stochastic dominance method onto Susenas data years 1984 and 1987. Additional adjustments were applied, especially on the price level in general and the rural areas' price level prediction. In addition, they also examined the decomposition of changes in the poverty measures into growth and redistribution effects. They concluded, in general, the poverty had declined in Indonesia from 1984 to 1987.

The research in Indonesia utilizing the stochastic dominance analysis on the welfare area continued. Ravallion (1992) underlined the other research's evidence that explains the less responsiveness of the energy intakes to the poor's income. The energy intakes then translated into undernutrition. By using the stochastic dominance method on the Susenas 1984 and 1987 data, he found that the aggregate undernutrition in Indonesia was responsive to the changes in prices and incomes.

Madden \& Smith (2000) employed the stochastic dominance analysis when assessing the poverty in Ireland in the period 1987 to 1994. They utilized two kinds of poverty lines, absolute and relative, to measure the poverty rate by using the Household Budget Survey data in Ireland. Eventually, they found that poverty in Ireland decreased in such period, in case absolute poverty lines are used. In addition, when they employed the relative poverty lines, there was stochastic dominance on the second order for expenditure data and the third order for income data.

Not only for examining the changes of welfare over some periods, the stochastic dominance analysis could also be imposed on the simulation's study. Makdissi \& Wodon (2002) applied the method when simulating the impact of the marginal tax reform on the poverty in Bolivia, 1999. They utilized the so-called Consumption Dominance Curve to investigate the robustness of poverty reduction over different poverty measures and poverty lines after the marginal tax reform was imposed on two commodities. They found that the increase in prices of medicines and the lower rate for interprovincial transportation would reduce any poverty measure of the second order, showing that the chosen particular order was essential in their analysis.

While the existed theory put the assumption that the continuity holds in incomes of households. Araar (2006) explained in his research about the discontinuity nature in real data. He compared Burkina Faso's data in 1994 and 1998 and using the stochastic dominance analysis for assumed discrete data. His research's result suggested that 
the poverty rate figures from 1994 and 1998 had not changed significantly since the stochastic dominance analysis proved that there were no robust conclusions regarding the poverty changes.

Estudillo, Sawada, \& Otsuka (2008) assessed the changes in households' income structure and poverty reduction in three villages in the Philippines using the data from 1985 to 2004. After finding that the headcount ratio reduced over the periods, they investigated the sensitiveness of the chosen poverty line. The result shows that the poverty indeed declined robustly after implementing the stochastic dominance analysis.

The stochastic dominance utilization was employed by Pinar, Stengos, \& Topaloglou (2013) to measure the progress of the Human Development Index (HDI). They used the HDI data from the United Nations Development Program in the period of 1975 to 2000. Their research eventually suggested the different rankings of countries based on the stochastic dominance test for the robust result.

Davidson \& Duclos (2013) studied the application of a newly stochastic dominance test on by employing the Luxembourg Income Study (LIS) that comprises USA data year 2000, the Netherland year 1999, the UK year 1999, Germany year 2000, and Ireland year 2000. They tried to overcome the classical problem for stochastic dominance test assumption which was the continuity of distributions. All in all, they suggested using the empirical likelihood methods in dealing with the continuous distribution of data.

Examining the ordinal variables was the focus of study by (2013). The study compared the data of Peruvian adults that living in Lima to the adults living elsewhere in Peru. The data's source was the Peruvian National Households Survey 2001 that covers 16,515 households. The results suggested that in this case, with the ordinal variables, the stochastic dominance method could be also imposed by deriving the ordinal-variable equivalent for the additive social welfare functions.

Levine, Muwonge, \& Batana (2014) examined the multidimensional poverty using the survey data in Uganda. The data, presented in 2000/2001 and 2005/2006, were obtained from the Uganda Bureau of Statistics and ORC Macro respectively. The weighted-stochastic-dominance analysis was imposed to robustly prove the declining in multi-dimensional poverty in Uganda. The study contrasted the poverty rate in Uganda using the monetary approach with the multi-dimensional poverty which revealed the big margin between the two measurements.

Donald \& Hsu (2016) utilized the data from the Canadian Family Expenditure Survey in 1978 and 1986 to explore the welfare changes due to a tax family income. In a further test, they employed the Kolmogorov-Smirnov (KS) test to statistically the stochastic dominance condition. Their study, somehow, underlined a new type of KS test they utilized and finally yielded the similar result compared with the previous KS type test.

Arndt, Hussain, Salvucci, Tarp, \& Østerdal (2016) were focusing their research on the comparison of the poverty measurements using the census data and the small-area estimation. In this study, the first-order stochastic dominance method was utilized in Mozambique. For the census data, 1997 and 2007 were the chosen periods while $1996 / 1997$ and 2008/2009 were for the survey's source periods. They concluded that the first-order stochastic dominance presents robust comparisons across many backgrounds of populations.

\section{2) Application in the Other Disciplines}

As the complementary documentation on how the stochastic dominance, and to show the further developments and modifications for the respected method on the other topics, some brief literature reviews are presented in an ascending period. Tzeng, Huang, \& Shih (2013) presented a paper that utilizes a so-called almost second-degree stochastic dominance to rank all observed distributions in the context of decision making.

On the other utilization, Al-Khazali, Lean, \& Samet (2014) employed the stochastic dominance in the field of finance which conducted to assess the dominance of the Islamic stock indexes to the conventional stock indexes. Their study examined the data in the two periods, 1996-2012 and 20012006. Their study, eventually, indicated that the Islamic investment exhibited a better performance in the global financial crisis periods.

Dupačová \& Kopa (2014) employed the firstorder stochastic dominance in their paper about portfolio optimization with some constraints. The stochastic dominance method was specifically employed in the area of discrete distribution with respect to a scenario. Further, Daskalakis, Deckelbaum, \& Tzamos (2015) studied the revenue maximization for the multiple-good monopoly condition. They examined the purchasers' distribution using the stochastic dominance method. It is evident that the stochastic dominance method not only has been developing but also be utilized in the wider scope of disciplines.

Alongside many kinds of literature examining the poverty and/or welfare progression in various places and times using the stochastic dominance analysis, and for the motivation to assess the poverty reduction progress in Tabalong from the other perspective, this paper aims to robustly determine whether the poverty in Tabalong regency move to a 
better condition. Against the chosen relative poverty lines presented by BPS, this paper also investigates the sensitiveness of a range of poverty lines to the poverty rate.

\section{METHOD}

\section{A. Data Selection}

To perform the poverty comparison analysis using the stochastic dominance method, the paper collected the Susenas data in the period 2013 and 2017; in particular, for Tabalong regency locus. For the exact number, the total samples are 550 and 557 for 2013 and 2017 respectively. To include the price levels' influence on the households' expenditure, the per capita households' expenditures are deflated with the Tanjung city CPI's. This paper set 2013 as the base year (CPI=100). To complete the description, some poverty indicators are included in this paper such as poverty line data, headcount ratio (Po), and inflations.

\section{B. Analysis Formulation}

This section elaborates the process of assessing the poverty analysis in Tabalong regency. The first step of the analysis is the extrapolation of the Tanjung city CPIs. In the stochastic dominance analysis, the data should be in the real value, meaning that the per capita consumptions should absorb the impact of price changes over the years.

Further, the year 2013 is chosen for the base year, in this case, the CPI in Tanjung city will be set equal to 100 . By maintaining the inflation rate at the same level, the extrapolation process is done by the basic inflation formula

$$
I n f_{t}=\left(\frac{C P I_{t}-C P I_{t-1}}{C P I_{t-1}}\right) x 100 \%
$$

where $I n f_{t}$ is the inflation rate in the period (year) $t$, $C P I_{t}$ is the $C P I$ in period $t, C P I_{t-1}$ is the $C P I$ in period $t-1$. The inflation rate is expressed in percent. Equation (6) can obtain the CPI values by rearranging into

$$
C P I_{t-1}=\left(\frac{C P I_{t} x 100}{100+\operatorname{Inf} f_{t}}\right)
$$

and

$$
C P I_{t}=\left(\frac{C P I_{t-1} x\left(100+I n f_{t}\right)}{100}\right)
$$

where $C P I_{t-1}=C P I_{2013}=100$ in the base year. Thus, the value of $C P I_{2014}$ and the years beyond can be extrapolated using equation (8). Thus, when all the CPI from 2013 to 2017 have been obtained, the per capita per month expenditures can be deflated with the ratio of $C P I$ in 2017 to the $C P I$ in the base year 2013 (100). To simplify the numbers, the per capita expenditures are expressed in form of natural logarithm (In).

The next step is forming a cumulative distribution function (CDF) for both years. For simplicity, this paper employs the STATA 13 to directly create two weighted CDFs for the per capita per month expenditure in the observed periods. Once created, the CDFs are then drawn by STATA in one figure. This step is to assess visually the stochastic dominance condition.

The last step is to test the dominance of those CDFs statistically. The test will be done from 2013 to 2017. Two-sample Kolmogorov-Smirnov test (as seen on Estudillo, Sawada, and Otsuka (2008)) is employed to check whether two nearby distribution is different or not. The difference between two distributions can be translated as the dominant position of a distribution on another. In case the stochastic dominance is done to investigates the dominance of a CDF over another to prove that the welfare has progressed robustly, then at the order $s$, the null hypothesis of Two-sample KS can be expressed as

$$
H_{0}=F_{A}-F_{B}=0
$$

where $F_{A}$ is the CDF for distribution $A$, and $F_{B}$ is the CDF for distribution $B$ in two different years. For the sensitiveness of the chosen poverty line, a range of deflated poverty lines in 2013 and 2017 will be attach of the CDFs figure to check whether the incident in Figure 3 occurs.

\section{RESULTS AND DISCUSSION}

\section{A. Tabalong's Poverty Lines Progression}

From 2013 to 2017, nominally, the poverty lines in Tabalong Regency increased around Rp100,000. As can be seen in Table 1, at the initial year of observation, the poverty line was set at Rp330,764 and increased by approximately $5 \%$ to $6 \%$ in the next period with the exception for 2016 poverty line (grew $10.23 \%$ from the previous year). Nominally, the increment of poverty lines in Tabalong regency in each year in a range of $\mathrm{Rp} 18,000$ to $\mathrm{Rp} 23,000$ (with the exception of 2016 poverty line that increased Rp37,745 significantly). 
Table 1.

Poverty Lines (PLs) in Tabalong Nominal Numbers (IDR), 2013 to 2017

\begin{tabular}{|c|c|c|c|c|c|c|}
\hline Year & $\begin{array}{l}\text { Nominal } \\
\text { PLs } \\
\text { (NPLs) }\end{array}$ & $\begin{array}{c}\text { Annual } \\
\text { NPLs' } \\
\text { Change } \\
(\%)\end{array}$ & $\begin{array}{l}\text { NPLs' } \\
\text { Nominal } \\
\text { Increase } \\
\text { (IDR) }\end{array}$ & $\begin{array}{l}\text { Po } \\
\text { (\%) }\end{array}$ & CPI & $\begin{array}{c}\text { Inflation } \\
\text { (\%) }\end{array}$ \\
\hline 2017 & 430,129 & 5.77 & 23,460 & 6.09 & 121.46 & 2.4 \\
\hline 2016 & 406,669 & 10.23 & 37,745 & 6.35 & 118.61 & 2.18 \\
\hline 2015 & 368,924 & 5.19 & 18,187 & 6.59 & 116.08 & 6.69 \\
\hline 2014 & 350,737 & 6.04 & 19,973 & 6.21 & 108.80 & 8.8 \\
\hline 2013* & 330,764 & $\mathrm{Na}$ & $\mathrm{Na}$ & 6.15 & 100.00 & 5.29 \\
\hline
\end{tabular}

Source: Statistics Indonesia (BPS), Author's calculation.

* Inflation in Tanjung 2013 was obtained from the local Cost Living Survey, BPS provided Tanjung's inflation starting from 2014.

In Table 1, the fluctuation of inflation and the annual nominal poverty lines (NPLs) can be examined. When in 2014 inflation $8.8 \%$ occurred, the NPLs increased by $6.04 \%$. However, when a relatively-lower inflation happened in 2016 by $2.18 \%$, the NPLs grew significantly by $10.23 \%$. This finding could not be put into our concluding note about the relationship between inflation and a poverty line concerning about the exception in the year 2016. Thus, examining the relationship between inflations and the poverty lines directly could bring dubious conclusions.

\section{B. Stochastic Dominance Analysis: The Graphical Inspection}

STATA 13 provides an easiness to draw two adjacent CDFs using its weight because in Susenas individual weight is given. Also, the CDFs can be

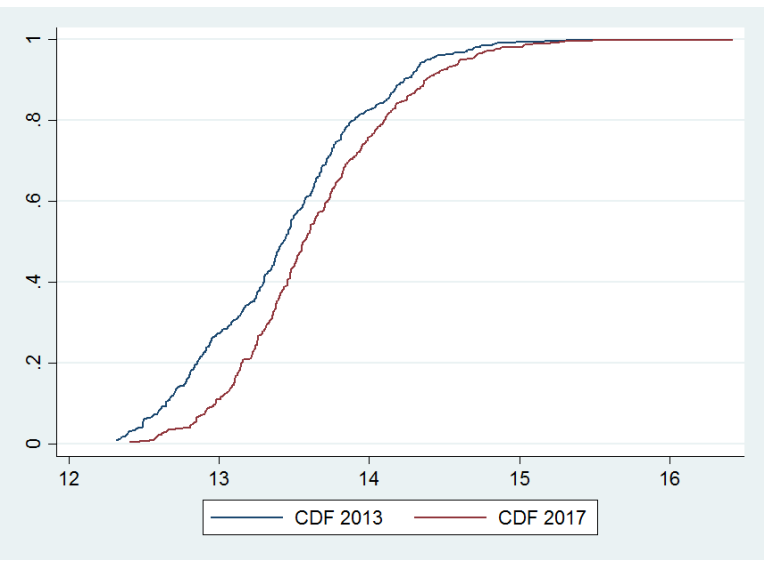

Figure 4. CDFs of Per Capita per Month Expenditures (ln) in Tabalong Regency 2013 and 2017 automatically sorted. The graphical analysis is important to determine initially whether the 2 CDFs are crossing or not. Furthermore, the relative distance between two curves also can be observed. To magnify the picture due to a large digit of per capita per month expenditure, the conversion to $\mathrm{ln}$ has been done. The poverty lines, in an approximate manner, are also converted.

Figure 4 depicts the two adjacent CDFs for per capita per month expenditures in Tabalong regency, for the period of 2013 and 2017. There are some notes can be taken regarding figure 4 . In general, the welfare in Tabalong regency has increased. This is shown by the movement of CDF in 2013 to the righthand side in 2017. There is no notable crossing CDFs in this case which can bring a robust conclusion about poverty reduction progress. Because the CDF in 2017 is mainly at the right-hand side of $2013 \mathrm{CDF}$,

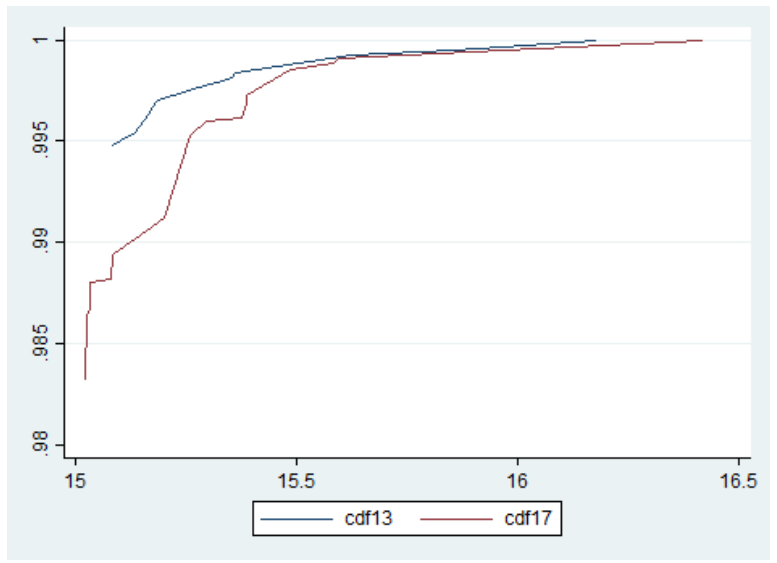

Figure 5. Magnified $C D F$ s of Per Capita per Month Expenditures (In) in Tabalong Regency 2013 and 2017 (Per Capita per Month Expenditures $\geq 15$ and $C D F$ value $\geq 0.985$ )

Source: STATA processing 


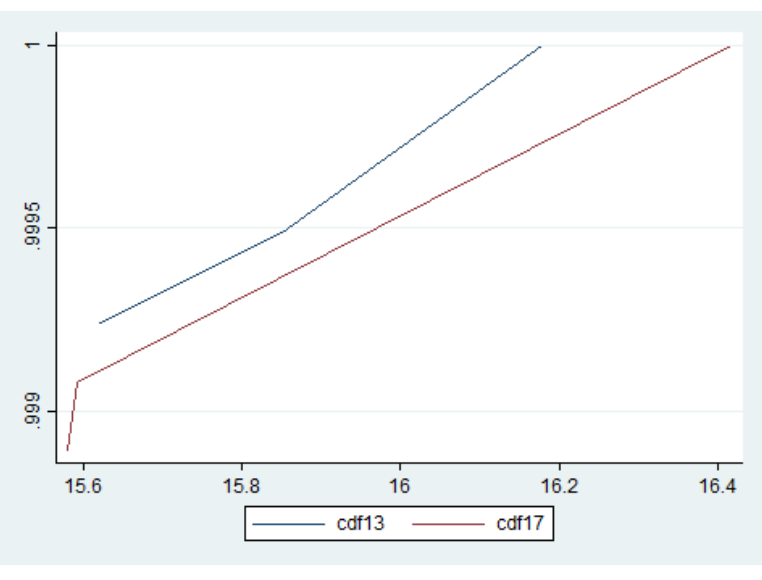

Figure 6. Magnified $C D F$ s of Per Capita per Month Expenditures (ln) in Tabalong Regency 2013 and 2017 (Per Capita per Month Expenditures $\geq 15.6$ and $C D F$ value $\geq 0.999$ )

\section{Source: STATA processing}

there is a conclusion that CDF in 2017 stochastically dominates the CDF in 2013 at the first order. In other words, there is a better welfare in 2017 compared to 2013. Moreover, the conclusion about the lower poverty in 2017 can be robustly proven based on the picture.

However, as described in Figure 4, for the value of ln per capita per month expenditures more than 15 , there is a closing CDFs. To examine the incidence of the crossing CDFs or when the difference between In per capita per month expenditures in 2017 to 2013 is negative $\left(\mathrm{CDF}_{2017}\right.$ is above $\left.\mathrm{CDF}_{2013}\right)$, we can put our focus on the value when ln per capita per month expenditures are more than 15 . Figure 5 provides the detailed figure when the value of $\ln$ per capita per month of expenditures after being sorted based on CDFs and bigger than 15 .

At a glance, in Figure 5, there is no incident that the $\mathrm{CDF}_{2013}$ crosses the $\mathrm{CDF}_{2017}$. In this position, there is no undoubting opinion that can prove the distribution in 2013 stochastically dominates the distribution in 2017 at the value of poverty line more than 15. However, at the CDF values ranging from 0.999 to 1 seem to need to be more magnified because the CDFs lines are so near. Therefore, the STATA now is set at such value as a boundary.
In Figure 6, the upper part of the two adjacent CDFs can be examined. After being magnified, it is easier to determine whether the $\mathrm{CDF}_{2017}$ fully dominates the $\mathrm{CDF}_{2013}$ at the upper side of those curves. After both distributions are sorted, there is evidence that $\mathrm{CDF}_{2017}$ always dominate $\mathrm{CDF}_{2013}$ at every level of the poverty line. Therefore, based on this condition, the distribution in 2017 is called robustly stochastically dominates the distribution in 2013 at every possible level of chosen poverty lines. This graph inspection, eventually, produces the initial conclusion that the welfare in 2017 increased compared with the welfare condition in 2013.

However, to legitimate the conclusion about the stochastic dominance of the distribution in 2017 to the distribution in 2013, the second-order of stochastic dominance can be performed. The $\mathrm{CDF}_{2017}$ can be considered stochastically dominates the $\mathrm{CDF}_{2013}$ at the second order if the total area beneath the $\mathrm{CDF}_{2013}$ is bigger than the area beneath the $\mathrm{CDF}_{2017}$ (in the poverty sense, the poverty gap of the distribution in 2013 is bigger than in 2017). Calculating the area under the CDFs is considerably sensitive to the outliers; so the highest data from both distribution are taken out. Therefore, the calculation result of the total area beneath both CDFs given by the table 2 .

Table 2 shows the integral calculation for the total area under both CDFs. It is obvious that the total area beneath the $\mathrm{CDF}_{2013}$ is bigger than the total area for the $\mathrm{CDF}_{2017}$ (2.428 vs. 1.976). Eventually, there is a conclusion that the distribution in 2017 stochastically dominates the distribution in 2013 at the second-order.

The next analysis that can be done to analyze the sensitivity of chosen poverty line to the poverty is by utilizing magnified-picture of figure 4 with the companion of converted poverty lines (PLs) in 2013 and 2017. The analysis can be seen from Figure 7.

In the converted poverty lines in 2013 and 2017, there are four points of the curves' intersection. When the poverty line in 2013 is utilized as the threshold for poverty criteria, CDF in 2017 dominates the CDF in 2013. This can be seen when $B$ is in the lower position compared to A (this can be also translated as the lower poverty

Table 2.

Integral Calculation for the CDF of ln per Capita per Month of Expenditures in 2013 and 2017 Using Tabalong Regency Data

\begin{tabular}{ccccc} 
Year & $\begin{array}{c}\text { Number of } \\
\text { Points }\end{array}$ & Integral & $\begin{array}{c}\text { Minimum } \\
\text { Value }\end{array}$ & $\begin{array}{c}\text { Maximum } \\
\text { Value }\end{array}$ \\
2013 & 549 & 2.4280763 & 12.31781 & 15.85112 \\
\hline 2017 & 556 & 1.976205 & 12.40699 & 15.59193 \\
\hline
\end{tabular}

Source: STATA calculation

Stochastic Dominance Analysis 
Table 3.

Descriptive Statistics and Hypothesis Testing Result for the Two-Sample KS Test Using Tabalong Regency Data, 2013 and 2017

\begin{tabular}{cccccccc} 
Variable & Observations & $\begin{array}{c}\text { Obs. } \\
\text { with } \\
\text { missing } \\
\text { data }\end{array}$ & $\begin{array}{c}\text { Obs. } \\
\text { without } \\
\text { missing } \\
\text { data }\end{array}$ & Min & Max & Mean & $\begin{array}{c}\text { Std. } \\
\text { deviation }\end{array}$ \\
Incapita2013 & 550 & 0 & 550 & 12.318 & 16.178 & 13.633 & 0.648 \\
\hline Incapita2017 & 557 & 0 & & 12.407 & 16.417 & 13.784 & 0.578 \\
\hline D & 0.125 & & & & & & \\
\hline p-value & $0.000^{* * *}$ & & & & & & \\
\hline alpha & 0.01 &
\end{tabular}

Source: XLSTAT calculation.

*** Indicates the D statistics is significant at $\alpha=1 \%$.

rate in $\mathrm{B}$ compared to $\mathrm{A}$ since $\mathrm{B}$ dominates $\mathrm{A}$ ). When the poverty line in 2017 is set as the boundary, the same situation also happens. Point D is lower than $\mathrm{C}$, meaning that poverty rate in 2017 is lower than in 2013. Eventually, whichever the poverty line is set, the distribution in 2017 always dominates the distribution in 2013. The analysis is quite clear because of no crossing incidence for the CDFs at the possible range of poverty lines. All in all, the welfare in 2017 is better than in 2013 with the insensitivity of the chosen poverty lines.

\section{Stochastic Dominance Analysis: Hypothesis Testing}

Further analysis is the hypothesis testing of dominance. One distribution is said to dominate another when the null hypothesis is cannot be accepted. By using the hypothesis in equation 9 and two-sample KS test, the result can be seen in table 3 .

Table 3 presents the summary statistics as well as the hypothesis testing results for the two-sample KS test for two adjacent CDFs in the observation. The test indicates that the $\mathrm{P}$ value is lower than $1 \%$, proving that the null hypothesis cannot be accepted; therefore, both distributions are assumed significantly different. In conclusion, the distribution in 2017 robustly dominated the distribution in 2013; the welfare has increased from 2013 to 2017 and the chosen poverty lines were not sensitive to the poverty.

The poverty headcount ratio in Tabalong regency in 2013 and 2017 were $6.15 \%$ and $6.09 \%$ respectively, meaning that there was a decline in the poverty rates in Tabalong. In line with those BPS' data, this paper also supports the conclusion that the welfare indeed inclined in the observed period. Eventually, regardless some researchers' considerations, the findings of this paper (as well as the method) can complement the BPS' official poverty data to produce a solid base for the poverty alleviation policy taken by the policymakers.

\section{ConClusion}

Investigating the welfare change in the reality that poverty rates (headcount ratio) fluctuated over the period is the motivation of this paper. This paper investigates the progress of the poverty reduction (i.e. welfare development) in Tabalong regency in 2013 to 2017. By using the per capita per month expenditures from Susenas data deflated by the extrapolated CPIs, the progress of welfare change has been examined.

The stochastic dominance method indicated that the welfare in Tabalong regency has robustly improved. This approach included the purchasing power impact (by adjusting the data in 2017 with the extrapolated CPIs) to the per capita per month expenditures of all samples. Distribution in 2017 stochastically dominated the distribution in 2013 at the first and the second order, this means in the real sense, the conclusion should have been absolute; moreover, with the additional examination for the upper part of both CDFs.

In a range of possible poverty lines, the robustness also stands still, the chosen poverty lines are then said to be insensitive to the poverty. There was no crossing curve of CDFs that supports the conclusion of the method (the welfare change was easier to be recognized).

In addition, the two-sample KS test also proved that both distributions are statistically different and the distribution in 2017 stochastically dominates 2013. As an additional note, the stochastic domination of the distribution in 2017 
to the distribution in 2013 cannot be considered restricted because of no evidence that showing the crossing incident of both CDFs.

Various methods of the stochastic dominance analysis have been being developed by many researchers. This paper presents the simple application of the stochastic dominance method on the poverty analysis. For further development, this method could also be mixed with the simulation analysis; for instance, the impact of a policy on the poverty/welfare at one particular time.

In the various concepts and calculation methods of the poverty threshold, the poverty rate analysis should not be taken as the only measurement of the poverty alleviation policy evaluation. The policymakers should also underline the other methods that accommodate the diversity of poverty analysis. Thus, this paper stands as an alternative as well as a complementary method to assess the welfare change. So, the policymakers could produce a solid conclusion regarding the poverty dynamics over a period.

\section{ACKNOWLEDGEMENT}

A good thought for all of my colleagues that supported me to construct this paper. I thank for BPS for the excellence data and website; also, for BPS of Tabalong regency that gave me the access to Susenas data. I also thank for the constructing comments from the reviewers. I responsible for all of the errors in this paper.

\section{REFERENCES}

Al-Khazali, O., Lean, H. H., \& Samet, A. (2014). Do Islamic stock indexes outperform conventional stock indexes? A stochastic dominance approach. Pacific-Basin Finance Journal, 28, 29-46. http://doi.org/10.1016/j. pacfin.2013.09.003

Araar, A. (2006). Poverty, Inequality and Stochastic Dominance, Theory and Practice: Illustration with Burkina Faso Surveys. CIRPEE Working Paper No. 06-34. http://doi.org/10.2139/ ssrn.938555

Arndt, C., Hussain, A. M., Salvucci, V., Tarp, F., \& Østerdal, L. P. (2016). Poverty Mapping Based on First-Order Dominance with an Example from Mozambique. Journal of International Development, 28(1), 3-21. http://doi. org/10.1002/jid.3200

Atkinson, A. B. (1987). On the Measurement of Poverty. Econometrica, 55(4), 749-764. http:// doi.org/10.2307/1911028

Daskalakis, C., Deckelbaum, A., \& Tzamos, C. (2015). Strong Duality for a Multiple-Good Monopolist. In Proceedings of the Sixteenth ACM Conference on Economics and Computation - EC '15 (pp. 449-450). New York, New York, USA: ACM Press. http://doi.org/10.1145/2764468.2764539

Davidson, R. (2006). Stochastic Dominance (Departmental Working Papers). McGill University, Department of Economics. Retrieved from https://ideas.repec.org/p/ $\mathrm{mcl} / \mathrm{mclwop} / 2006-19 . \mathrm{html}$

Davidson, R., \& Duclos, J.-Y. (2000). Statistical Inference for Stochastic Dominance and for the Measurement of Poverty and Inequality. Econometrica, 68(6), 1435-1464. http://doi. org/10.1111/1468-0262.00167

Davidson, R., \& Duclos, J.-Y. (2013). Testing for Restricted Stochastic Dominance. Econometric Reviews, 32(1), 84-125. http://doi.org/10.108 0/07474938.2012.690332

Donald, S. G., \& Hsu, Y.-C. (2016). Improving the Power of Tests of Stochastic Dominance. Econometric Reviews, 35(4), 553-585. http:// doi.org/10.1080/07474938.2013.833813

Dupačová, J., \& Kopa, M. (2014). Robustness of optimal portfolios under risk and stochastic dominance constraints. European Journal of Operational Research, 234(2), 434-441. http:// doi.org/10.1016/j.ejor.2013.06.018

Estudillo, J. P., Sawada, Y., \& Otsuka, K. (2008). Poverty and Income Dynamics in Philippine Villages, 1985-2004. Review of Development Economics, 12(4), 877-890. http://doi. org/10.1111/j.1467-9361.2008.00458.x

Foster, J. E., \& Shorrocks, A. F. (1988). Poverty Orderings and Welfare Dominance. In Distributive Justice and Inequality (pp. 91-110). Berlin, Heidelberg: Springer Berlin Heidelberg. http://doi.org/10.1007/978-3-642-738166_6

Foster, J., Greer, J., \& Thorbecke, E. (1984). A Class of Decomposable Poverty Measures. Econometrica, 52(3), 761-766. http://doi. org/10.2307/1913475

Khomsan, A., Dharmawan, A. H., Saharuddin, Alfiasari, Sukandar, D., \& Syarief, H. (2015). Indikator Kemiskinan dan Misklasifikasi Orang Miskin. Jakarta: Yayasan Pustaka Obor Indonesia.

Lanjouw, J. O. (1998). Demystifying Poverty Lines. Retrieved from http://siteresources. worldbank. or g / P G L P / Re s ources / LanjouwDemystifyingPovertyLines.pdf

Levine, S., Muwonge, J., \& Batana, Y. M. (2014). A Robust Multi-dimensional Poverty Profile for Uganda. Journal of Human Development and Capabilities, 15(4), 369-390. http://doi.org/1 $0.1080 / 19452829.2014 .897310$

MacPherson, S., \& Silburn, R. (1998). The meaning and measurement of poverty. In J. Dixon \& D. 
Macarov (Eds.), Poverty: A Persistent Global Reality (pp. 1-19). London \& New York: Routledge.

Madden, D., \& Smith, F. (2000). Poverty in Ireland, 1987-1994: A Stochastic Dominance Approach. The Economic and Social Review, 31(3), 187-214. Retrieved from http://hdl.handle. net/2262/60131

Makdissi, P., \& Wodon, Q. (2002). Consumption dominance curves: testing for the impact of indirect tax reforms on poverty. Economics Letters, 75(2), 227-235. http://doi. org/10.1016/S0165-1765(01)00599-7

Marbun, D., \& Suryahadi, A. (2009). Kriteria Kemiskinan Konsumsi: Praktik di Indonesia dan Beberapa Catatan. Jurnal Analisis Sosial, 14(2), 13-30. Retrieved from http://www. akatiga.org/index.php/jurnal-analisis-sosial/ item / 468-jas-vol-14-no-2-menelusurikriteria-kemiskinan-perspektif-masyarakatsipil

Pinar, M., Stengos, T., \& Topaloglou, N. (2013). Measuring human development: a stochastic dominance approach. Journal of Economic Growth, 18(1), 69-108. http://doi. org/10.1007/s10887-012-9083-8

Ravallion, M. (1992). Does Undernutrition Respond to Incomes and Prices? Dominance Tests for Indonesia. The World Bank Economic Review, 6(1), 109-124. http://doi.org/10.1093/ wber/6.1.109

Ravallion, M., \& Huppi, M. (1991). Measuring Changes in Poverty: A Methodological Case Study of Indonesia during an Adjustment Period. The World Bank Economic Review, 5(1), 57-82. http://doi.org/10.1093/wber/5.1.57

Statistics Indonesia (BPS). (2009). Analisis Kemiskinan, Ketenagakerjaan dan Distribusi
Pendapatan. Jakarta: Statistics Indonesia (BPS). Retrieved from https://www. bps.go.id/publication/2009/03/04/ bfe 286 bb 431 babaad $062642 \mathrm{f} /$ analisiskemiskinan-ketenagakerjaan-dan-distribusipendapatan.html

Statistics Indonesia (BPS). (2016). Penghitungan dan Analisis Kemiskinan Makro Indonesia Tahun 2016. Jakarta: Statistics Indonesia (BPS). Retrieved from https://microdata.bps.go.id/ mikrodata/index.php/citations/346

Statistics of South Kalimantan Province (BPS Provinsi Kalimantan Selatan). (2017). Jumlah Penduduk Miskin Menurut Kabupaten/Kota di Provinsi Kalimantan Selatan Tahun 19962016. Retrieved from https://kalsel.bps.go.id/ dynamictable/2017/06/20/973/jumlahpenduduk-miskin-menurut-kabupatenkota-di-provinsi-kalimantan-selatantahun-1996-2016.html

Susilowati, S. H. (2010). Pendekatan Skala Ekivalensi untuk Mengukur Kemiskinan. Forum Penelitian Agro Ekonomi, 28(2), 91-105. http://doi. org/10.21082/fae.v28n2.2010.91-105

Suyanto, B. (2001). Kemiskinan dan Pemberdayaan Masyarakat Miskin. Masyarakat, Kebudayaan Dan Politik, XIV(4), 25-42. Retrieved from http://web.unair.ac.id/admin/file/f_19997_ jr3.pdf

Tzeng, L. Y., Huang, R. J., \& Shih, P.-T. (2013). Revisiting Almost Second-Degree Stochastic Dominance. Management Science, 59(5), 1250-1254. http://doi.org/10.1287/mnsc.1120.1616

Yalonetzky, G. (2013). Stochastic Dominance with Ordinal Variables: Conditions and a Test. Econometric Reviews, 32(1), 126-163. http:// doi.org/10.1080/07474938.2012.690653 